\title{
Kebijakan Pajak Indonesia Menanggapi Krisis COVID-19: Manfaat bagi Wajib Pajak
}

\section{Aswin Padyanoor ${ }^{1}$ \\ Fakultas Ekonomi dan Bisnis Universitas Airlangga, Indonesia}

Surel : aswinpadyanoor@gmail.com

\section{ABSTRAK}

Ekonomi berubah secara dramatis, sejak wabah COVID-19 menyebar. Dampak yang terjadi di Indonesia akibatnya hampir disemua lini, kebijakan terus diterbitkan oleh pemerintah akibat dampak ini. Kebijakan pajak yang dibuat untuk dapat memberikan insentif bagi Wajib Pajak yang terkena dampak, penggunaannya diperkirakan akan meningkat pertumbuhan ekonomi. Penelitian ini dilakukan untuk memetakan 14 Kebijakan Pajak dalam tiga Peraturan yang diterbitkan oleh Pemerintah berdasarkan tujuan mengurangi dampak ekonomi akibat pandemi COVID-19. Penelitian menggunakan metode kualitatif dengan pendekatan deskriptif yang diperoleh dengan data sekunder. Kemudian melakukan analisis data menggunakan tiga tahapan teknik analisis dalam bentuk pengumpulan data, pengurangan data, dan penarikan kesimpulan. Hasil penelitian menyatakan bahwa Indonesia telah menerbitkan kebijakan untuk membantu Wajib Pajak yang terena dampak COVID-19. Manfaat bagi Wajib Pajak yaitu penurunan tarif sampai dengan pembebasan atas pajak penghasilan, tujuannya agar ekonomi yang berhenti dapat bergerak naik menjadi stabil.

Kata Kunci: $\quad$ Insentif Pajak; Kebijakan Pajak; Wajib Pajak.

\section{Tax Policy Indonesia In Response To The COVID-19 Crisis: Benefits For Taxpayers}

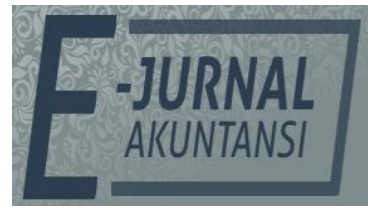

e-ISSN 2302-8556

Vol. 30 No. 9

Denpasar, September 2020

Hal. 2216-2230

DOI:

10.24843/EJA.2020.v30.i09.p04

PENGUTIPAN:

Padyanoor, A. (2020).

Kebijakan Pajak Indonesia Menanggapi Krisis COVID19: Manfaat bagi Wajib Pajak. E-Jurnal Akuntansi, 30(9), 2216-2230

RIWAYAT ARTIKEL: Artikel Masuk: 19 Juni 2020 Artikel Diterima: 24 Agustus 2020

\section{ABSTRACT}

The economy has changed dramatically since the COVID-19 outbreak began. The impact that occurred in Indonesia was almost on all fronts, and the Government continued to issue policies due to this impact. Tax policies that are designed to provide incentives for affected taxpayers are expected to increase economic growth. This research was conducted to map 14 Tax Policies in three Regulations issued by the Government based on the objective of reducing the economic impact of the COVID19 pandemic. The study used a qualitative method with a descriptive approach obtained. Then perform data analysis using three stages of analysis techniques in the form of data collection, data reduction, and concluding. The results of the study state that Indonesia has issued a policy to help taxpayers who are affected by COVID-19. Benefits for taxpayers, namely a reduction in rates to an exemption from income tax, the goal is that the economy which has stopped moving up becomes stable.

Keywords: $\quad$ Tax Incentives; Tax Policy; Taxpayers.

Artikel dapat diakses : https://ojs.unud.ac.id/index.php/Akuntansi/index 


\section{PENDAHULUAN}

Pemandangan ekonomi hari ini telah berubah secara dramatis. Pandemi global Corona Virus atau sering disebut COVID-19 dan penyempitan kegiatan ekonomi yang terjadi saat ini membuat ekonomi tidak bergerak, dengan pandangan bahwa Covid menggiring ekonomi kepada resesi yang berkepanjangan dan semakin lebih parah yang akan terjadi (Muhyiddin \& Wardhana, 2020). Besarnya goncangan ekonomi dunia juga tidak menentu, seperti halnya saat ini. Namun, banyak yang khawatir bahwa penurunan tingkat PDB global akan terus berubahubah. Bahkan, mungkin pada skalanya akan lebih buruk dari resesi yang telah Indonesia lalui ditahun-tahun yang lalu.

COVID-19 klasifikasikan sebagai virus yang penyebarannya dan membawa dampak infeksi pada saluran pernapasan atas dari ringan hingga sedang, diagnosisnya dimulai dengan gejala umum berupa demam, batuk dan flu hingga kesulitan bernapas (Sampurno, Kusumandyoko, \& Islam, 2020) dan (Yuliana, 2020). Terdapat tujuh jenis COVID-19 (HCoVs) yang telah tercatat dan diidentifikasi, yaitu (1) HCoV-229E (2) HCoV-OC43, (3) HCoV-NL63, (4) HCoVHKU1, (5) SARS-COV, (6) MERS-COV, dan (7) COVID-19 (CNN Indonesia, 2020). COVID-19 diambil dari kata yang merupakan singkatan dari kata corona menjadi "CO", virus menjadi "VI", dan disease menjadi " $\mathrm{D}$ ", serta angka 19 yang mewakili tahun 2019 menjelaskan saat virus ditemukan dan di identifikasi.

\section{Kasus COVID-19 Indonesia}

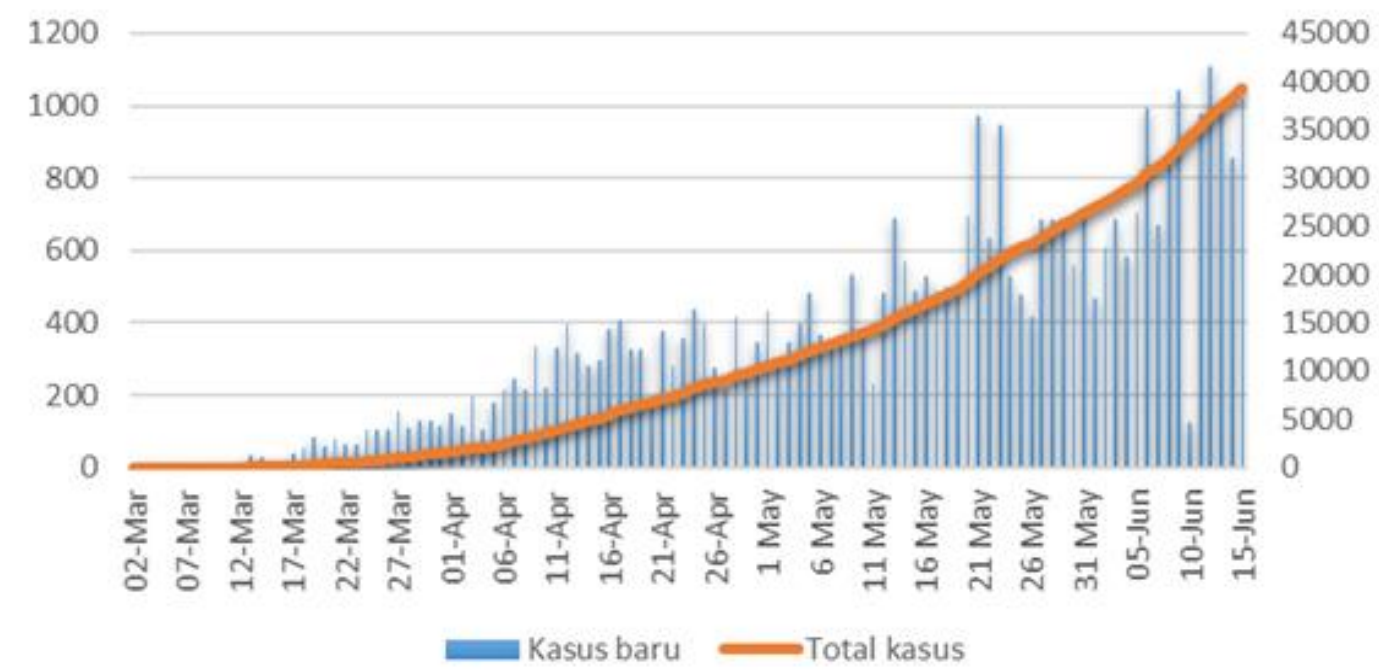

Sumber: Data Penelitian, 2020

Gambar 1. Kasus COVID-19 Indonesia

Awal ditemukan dan menyebar wabah ini ada di Ibu kota Provinsi Hubei, Wuhan, Tiongkok di penghujung tahun 2019 yaitu bulan Desember. Virus ini terus menyebar ke negara diluar Tiongkok, seiring banyak negara yang melaporkan kasus wabah COVID-19. Hanya ada sedikit negara telah berhasil mengimplementasi kebijakannya untuk membuat penyebaran COVID-19 dapat terkendali, tetapi itu tidak dapat secara efektif menjamin bahwa sebaran COVID19 akan hilang dengan cepat (Faisal \& Nirmala, 2020). Mulai menyebarkan dampak ke negara-negara lain pada bulan Januari 2020 dan awal mula masuk 
Indonesia setelah diumumkan bahwa ada laporan kasus COVID-19 dibulan awal bulan Maret 2020, lebih tepatnya pada hari Senin, 2 Maret 2020 yakni dua warga Indonesia telah terjangkit Virus Corona, tepatnya di kota Depok, Jawa Barat. Informasi ini secara langsung disampaikan oleh Presiden Joko Widodo (Ihsanuddin, 2020). Menurut laporan WHO pertanggal 15 Juni 2020 dilaporkan kasus COVID-19 di Indonesia tercatat sebanyak 33.277 Kasus, menjadi negara kedua dalam kasus konfirmasi tertinggi negara terjangkit di ASEAN setelah Singapura sebanyak 40.604 Kasus (WHO, 2020).

Dampak yang terjadi di Indonesia karena pandemi COVID-19 ini hampir disemua sektor, mulai dari ketenagakerjaan sampai dengan kinerja industri segala sektor di dalam negeri. Selama pemberlakuan penghindaran penyebaran COVID-19 dengan mengubah pola kerja dan budaya kerja sebagian besar usaha di Indonesia, karena menyebabkan banyak pekerjaan ditunda dan akan berberdampak pada produktivitas kerja yang menurun (Mustajab et al., 2020). Terlihat jelas pada pihak yang terdampak yaitu di Usaha Mikro, Kecil, dan Menengah (UMKM), korporasi dan sektor keuangan serta di rumah tangga juga terkena dampaknya (Antara, Pryanka, \& Candra, 2020). Karena berkepanjangannya pandemi ini sehingga menyebabkan menurunnya kinerja industri dalam hal pengolahan dan pengerjaan, mulai dari produksi barang, permintaan produk baru, demikian juga terkait dengan ketenagakerjaan yang mana sampai pekerja banyak yang dirumahkan dan kena Pemutusan Hubungan Kerja (PHK).

Produk Domestik Bruto (PDB) per kapita Indonesia per tahun pada 2019 adalah USD 4.174,9 atau Rp 59,1 juta (kurs Rp 14.156- per USD). Dengan jumlah penduduk 267 juta jiwa, maka PDB Indonesia pada 2019 adalah sebesar Rp 15.833,9 Triliun (Hadiwardoyo, 2020). Semula diperkirakan sebesar 5,3\% Pertumbuhan ekonomi Indonesia pada 2020, Namun sebagian kalangan memprediksi proyeksi pertumbuhan ekonomi Indonesia tidak akan tumbuh tetapi menurun dikisaran 2,1\% dan negatif 3,5\% sebagai dampak pandemi COVID-19 (Hadiwardoyo, 2020) dan (Muhyiddin \& Wardhana, 2020).

Dari arus masuk dan keluar barang dari luar dan dalam negeri yang paling banyak disoroti adalah impor yang pada triwulan I 2020 ini turun menjadi 3,7\% year to date. Akibatnya juga berdampak bagi Inflasi pada bulan Maret 2020 mencapai $2,96 \%$ year on year. Dilihat dari sektor pariwisata juga mengalami penurunan okupansi, yaitu dari hotel turun hingga 50 persen, akibat dari kunjungan turis yang turun dan penerbangan di beberapa bandara dibatalkan sepanjang Januari-Mei 2020.

Pembuat kebijakan yaitu Pemerintah telah melakukan segala upaya dalam mengurangi dampak yang terjadi. Pada masa pandemi saat ini, banyak kebijakan dibuat untuk merangsang keadaan untuk semua lini yang terdampak mengalami penurunan atau perlambatan agar dapat naik kembali dan laju pertumbuhannya kembali sesuai dengan koridor yang diinginkan pemerintah. Kebijakan perlu mengacu pada permasalahan yang sedang dihadapi oleh masyarakat. Ketetapan yang diterbitkan oleh pemerintah atau lembaga kepemerintahan untuk menangani permasalahan tersebut, dan mencapai tujuan khusus yang berkaitan dengan pemenuhan kebutuhan, keperluan dan keuntungan kepada masyarakat. Sehingga penetapan kebijakan harus dilandasi 
dengan tujuan pencapaian penyelesaian permasalahan yang sedang dihadapi (Ramdhani \& Ramdhani, 2017) dan (Widyaningtyas, 2020).

Kebijakan pajak yang dibuat pemerintah dimaksudkan untuk memberikan insentif bagi Wajib Pajak (WP) yang terkena dampak wabah virus corona dengan menerbitkan PMK No. 44/2020, tentang Insentif Pajak untuk membantu dan melindungi Wajib Pajak yang terdampak dalam penurunan ekonomi saat ini. Beberapa insentif yang diberikan terkait, Pajak Penghasilan (PPh) Ps. 21 yang ditanggung oleh pemerintah, lalu pembebasan atas baraang impor (Pajak Penghasilan (PPh) Ps. 22), Ada juga terkait pengurangan tarif angsuran Pajak Penghasilan (PPh) Ps. 25, dan percepatan restitusi (Munandar, 2020). Kebijakan-Kebijakan lain juga dibuat untuk mengurangi dampak pandemi COVID-19. Dikeluarkan kebijakan oleh pemerintah terkait perpajakan bertujuan untuk membantu meningkatkan dan mempercepat arus keuangan dan barang serta produksi agar menjadi stabil dan mampu bertahan dalam masa pandemi serta mensejahterakan semua yang akan merasakan manfaat dari kebijakan ini.

Berdasarkan penjelasan bahwa setiap kebijakan yang telah diberikan oleh pemerintah diprediksi akan memberikan dampak lebih baik dalam meningkatkan dan mempercepat pertumbuhan ekonomi. Salah satunya dalam kebijakan pajak yang diberlakukan perlu diapresiasi dan oleh Wajib Pajak untuk dapat dioptimal pemanfaatan pada masa pandemi COVID-19 sedikit banyak membantu meringankan dan memberikan manfaat pada bisnis Wajib Pajak. Oleh karena itu tujuan peneliti ingin melakukan penelitian dengan tujuan untuk memetakan jumlah kebijakan pajak yang telah dikeluarkan oleh pemerintah Indonesia berdasarkan sudut pandang tujuan kebijakan pajak untuk manfaat bagi Wajib Pajak.

\section{METODE PENELITIAN}

Peneliti menggunakan pendekatan kualitatif dengan penelitian lebih kearah deskriptif, yaitu penelitian yang menggambarkan akan suatu kejadian yang menjadi fenomena penelitian, kemudian menjelaskan keadaan tersebut berdasarkan data-data yang ditemukan dan memiliki basis analisis (Hamzah, 2019). Adapun data diambil untuk penelitian ini adalah data sekunder, yang merupakan hasil data yang didapat secara tidak langsung, dimana peneliti memperoleh data sekunder dari berbagai referensi sumber yang telah secara langsung dikumpulkan seperti data, peraturan, literatur dan bacaan serta sumber lainnya yang berkaitan dengan penelitian sebagaimana pengumpul data secara langsung (Moleong, 1999). Analisis data dilakukan menggunakan tiga tahapan teknik menganalisis data berupa (1) data dikumpulkan, (2) pengurangan data dan (3) mengambil kesimpulan dari penelitian (Arvita \& Sawarjuwono, 2020).

\section{HASIL DAN PEMBAHASAN}

Tabel 1, adalah Kebijakan Pajak oleh Negara Anggota ASEAN, data didapat dari Organisation for Economic Co-operation and Development (OECD) yaitu organisasi internasional yang beroperasi pada fokus kelompok kerjasama ekonomi dan pembangunan.

Kebijakan yang telah dilakukan oleh negara anggota ASEAN tercatat dalam data OECD, berikut kriteria ukuran kebijakan pajak menurut OECD yaitu 
(1) Dukungan kredit dan likuiditas untuk bisnis, (2) Hak manfaat pajak yang ditingkatkan, (3) Dukungan pendapatan untuk individu yang paling membutuhkannya, (4) Dukungan pendapatan jangka panjang untuk pekerja yang kehilangan pekerjaan mereka atau menghadapi jam kerja berkurang sebagai hasil COVID-19, (5) Mengukur untuk meningkatkan arus kas bisnis, (6) Langkah untuk meningkatkan arus kas perusahaan, (7) Mengukur untuk mendukung sistem kesehatan, (8) Transfer tunai lebih banyak, (9) Ukuran nonpajak lainnya, (10) Ukuran kebijakan pajak lainnya, (11) Kebijakan pajak mendukung konsumsi, (12) Kebijakan pajak - mendukung pekerjaan, (13) Kebijakan pajak - mendukung investasi, (14) Dukungan pendapatan sementara untuk pekerja dan orang tua, (15) Subsidi upah sementara untuk pengusaha kecil.

Tabel 1. Kebijakan Pajak Negara ASEAN

\begin{tabular}{cc}
\hline Negara & Jumlah Kebijakan \\
\hline Singapore & 17 \\
Indonesia & 14 \\
Cambodia & 13 \\
Thailand & 7 \\
Laos & 5 \\
Malaysia & 5 \\
Myanmar & 3 \\
Vietnam & 3 \\
Philipines & 2 \\
Brunei Darusallam & - \\
Timor Leste & - \\
\hline
\end{tabular}

Sumber: Data OECD, 2020

Menurut data yang dimiliki oleh OECD negara anggota ASEAN paling banyak mengeluarkan pernyataan kebijakan pajak adalah negara Singapura dimana pemerintahnya telah mengeluarkan 17 pernyataan berada diposisi pertama, lalu kedua yaitu indonesia sebanyak 14 pernyataan dan ketiga kamboja sebanyak 13 pernyataan, tiga negara teratas ini adalah paling banyak mengeluarkan kebijakan pajak pada masa pandemi COVID-19 dibandingkan negara anggota ASEAN lainnya. Untuk negara anggota ASEAN lainnya telah mengeluarkan pernyataan kebijakan pajak pada masa pandemi COVID-19 kurang dari sepuluh pernyataan seperti Thailand 7, Laos 5, Malaysia 5, Myanmar 3, Vietnam 3, Filipina 2 pernyataan dalam menyatakan kebijakan pajak pada masa pandemi (Economic Organisation for Co-operation and Development, 2020).

Dalam kebijakan pajak tersebut mencakup kriteria-kriteria antara lain yaitu hak manfaat pajak seperti kebijakan pajak atas dana bantuan usaha dan subsidi kepada wiraswasta, lalu mengukur untuk meningkatkan arus kas bisnis seperti kebijakan tentang skema pinjaman atau jaminan, peningkatan ketentuan penyeimbangan kerugian, mempercepat atau meningkatkan ketentuan depresiasi pajak, pengembalian atau penangguhan pembayaran pajak, pengurangan tarif pajak penghasilan badan atau penghasilan pribadi, subsidi upah dibayarkan kepada pengusaha, kebijakan pajak mendukung pekerjaan, dan mendukung investasi, keringanan pajak, dan lainnya yang terkait dengan 
perpajakan serta ukuran non-pajak lainnya seperti kebijakan pajak penangguhan biaya bisnis (bukan upah).

Kebijakan Pajak Indonesia dalam masa Pandemi COVID-19, kebijakan diterbitkan yang diberlakukan untuk dapat menjaga tercapai perolehan dana dari pajak dan efektivitas pengumpulannya. Salah satu kebijakan pajak adalah penetapan tarif pajak, maka perlu untuk membuat kebijakan oleh pemerintah atas penetapan tarif pajak yang sesuai atau efektif yang berimbas positif terhadap nilai investasi (Harahap, Sinaga, Manurung, \& Maulana, 2018). Harapannya untuk menahan dampak pandemi virus corona pada ekonomi Indonesia. Pemerintah telah mengeluarkan 14 pernyataan kebijakan pajak dirangkum oleh data yang dikeluarkan OECD diantaranya berkaitan tentang pengurangan tarif pajak penghasilan badan, penangguhan pembayaran pajak, tingkat limit restitusi, penangguhan pembayaran pajak, keringanan pajak, dan lainnya berkaitan tentang perpajakan pada masa pandemi COVID-19. Dari 14 pernyataan tersebut tertuang dalam Peraturan Pemerintah (PP), Peraturan Menteri Keuangan (PMK) dan Peraturan Direktur Jenderal Pajak (PER Dirjen Pajak).

Pernyataan kebijakan pajak telah diklasifikasikan menurut data OECD menemukan bahwa sebanyak 7 kebijakan terkait dengan keringanan pajak yang berhubungan langsung dengan pajak pendapatan usaha perusahaan, pajak pendapatan orang pribadi dan pajak konsumsi dalam hal biaya impor barang konsumsi. Kemudian masing-masing sebanyak 2 kebijakan pajak terkait penangguhan pajak dan restitusi pajak.

Terdapat satu kebijakan pajak yang sangat membantu Wajib Pajak khususnya WP Badan dalam hal penurunan tingkat pajak pendapatan perusahaan. Langkah ini diambil oleh pemerintah untuk membantu dan melindungi bisnis Wajib Pajak dari adalnya likuidasi pada waktu mendatang akan lebih semakin berat. Kebijakan terkait pajak, diambil dengan tujuan utamanya oleh pemerintah merupakan dasar yang dipengaruhi keadaan pandemi COVID-19 yaitu terkait dalam hal mendukung sistem Kesehatan yang membantu penanganan dan penanggulangan wabah pandemi COVID-19. Pemerintah memberikan insentif pajak untuk barang-barang dan jasa-jasa yang diperuntukan dalam menanggulangi pandemi COVID-19 antara lain atas pajak pertambahan nilai, pajak penghasilan usaha dan pajak impor terbitlah PMK No. 28/2020.

Dalam 11 (sebelas) pernyataan tersebut telah dikeluarkan dengan Peraturan Menteri Keuangan yaitu PMK No. 44/2020 tentang Insentif Perpajakan untuk Wajib Pajak yang Terkena Dampak Pandemi COVID-19, yang mulai diberlakukan pada tanggal 27 April 2020, lebih lanjut peraturan tersebut telah diperbaharui oleh Pemerintah secara efektif untuk memperluas langkahlangkah insentif pajak yang sebelumnya yang ditetapkan oleh PMK No. 23/2020 tentang Insentif Perpajakan untuk Wajib Pajak yang Terkena Dampak COVID-19 (Menteri Keuangan Republik Indonesia, 2020a, 2020c).

Pertama, Insentif Pasal 21 Pajak Penghasilan Ditanggung Pemerintah. Berdasarkan peraturan ini, Langkah yang diambil oleh pemerintah yaitu menanggung Pajak Penghasilan (PPh) Ps. 21 dari karyawan, semestinya dipotong dari penghasilan karyawan. maka pemberi kerja harus menetapkan 
Karyawan memenuhi kriteria berikut untuk mendapatkan Ps. 21 Ditanggung Pemerintah (DTP) Pajak Penghasilan.

Seorang Karyawan yang mendapat penghasilan dari pemberi kerja dengan parameter yaitu (1) Pemberi Kerja (WP Badan) dengan kode Klasifikasi lapangan usaha (KLU) sesuai aturan PMK, (2) ditetapkan sebagai pelaku usaha Fasilitas Impor yang Berorientasi Ekspor (KITE) berdasarkan Keputusan Menteri Keuangan, atau (3) telah mendapat izin Operator Kawasan Berikat, izin Pengusaha Kawasan Berikat, atau izin untuk Pengusaha di Kawasan Berikat yang juga bertindak sebagai Operator di Kawasan Berikat (izin PDKB). Karyawan tersebut telah Memiliki Nomor Pokok Wajib Pajak (NPWP) dan Menerima pendapatan penghasilan kotor tahunan yang tidak melebihi Rp 200 juta pada tahun pajak terkait.

Pajak Penghasilan (PPh) Ps. 21 DTP harus dibayar tunai oleh pengusaha pada saat pembayaran pendapatan kepada karyawan dan itu tidak akan dihitung sebagai penghasilan kena pajak. Selanjutnya, insentif ini akan diberikan sejak Periode Masa Pajak April Tahun 2020 hingga September Tahun 2020. Dalam prosedur yang diperlukan untuk menerapkan insentif Pasal 21 DTP Pajak Penghasilan Pemberi kerja yang masuk dalam kriteria harus menyerahkan laporan realisasi DTP Pajak Penghasilan Pasal 21 menggunakan formulir di bawah lampiran E PMK 44/2020 melalui DJP Online, bersama dengan Slip Pembayaran Pajak atau Kode Penagihan, selambatnya pada tanggal 20 bulan berikutnya setelah periode masa pajak berakhir. Jika seorang karyawan yang menerima DTP Pajak Penghasilan Ps. 21, pada saat menyerahkan SPT Pajak Penghasilan Pribadi Tahunan untuk Tahun Pajak di 2020 dan menyatakan lebih bayar, maka kelebihan pembayaran tersebut yang berasal dari Pasal 21 DTP Pajak Penghasilan tidak diperbolehkan untuk dikembalikan. Manfaat bagi Wajib Pajak adalah tambahan penghasilan yang diterima, karena ditanggungnya pajak atas penghasilan yang selama ini telah dipotongkan langsung kepada Wajib Pajak karyawan. Manfaat ini dapat dirasakan secara langsung oleh Wajib Pajak karyawan dengan kriteria yang berlaku sesuai PMK 44/2020.

Kedua, Insentif Pajak Penghasilan (PPh) Final yang Ditanggung Pemerintah Indonesia didominasi dengan tujuan dimanfaatkan kebijakan ini bagi pelaku Usaha Mikro, Kecil, dan Menengah (UMKM) sebagai salah satu pembangkit perekonomian nasional yang juga terdampak secara serius pada aspek-aspek seperti total produksi dan nilai perdagangan, menyebabkan turunnya kinerja dari sisi permintaan (konsumsi dan daya beli masyarakat) yang akhirnya berdampak pada tenaga kerja yang harus dirumahkan atau kehilangan pekerjaannya karena pandemi COVID-19 (Pakpahan, 2020).

Pajak Penghasilan (PPh) Final ditanggung Pemerintah untuk UMKM. Insentif ini ditujukan untuk Wajib Pajak dengan angka penjualan di bawah Rp 4,8 miliar yang dalam bentuk Pajak Penghasilan (PPh) Final sebesar 0,5\% ditanggung Pemerintah (DTP Pajak Penghasilan Final) Dari jumlah peredaran bruto. Dengan begitu, Wajib Pajak tidak perlu membayar pajak, insentif tersebut diberikan untuk Periode Masa Pajak April tahun 2020 hingga September tahun 2020. Untuk mendapatkan insentif ini, Wajib Pajak UMKM harus menyerahkan permohonan kepada Direktorat Jenderal Pajak melalui DJP Online. WP UMKM wajib untuk dapat menyerahkan laporan tentang realisasi DTP Pajak 
Penghasilan Final mereka menggunakan formulir yang telah tersedia melalui DJP Online, bersamaan dengan Slip Pembayaran Pajak atau Kode Penagihan, selambatnya tanggal 20 bulan berikutnya setelah tanggal periode masa pajak berakhir. Manfaatnya bagi Wajib Pajak UMKM adalah untuk dapat berinovasi dalam usaha dan bertahan pada masa pandemi, insentif dari pemerintah dapat menjadi tambahan modal usaha disaat seperti ini.

Ketiga, Insentif Pajak Penghasilan (PPh) Ps. 22 atas Impor yaitu pembebasan pemungutan atas impor oleh Bank Devisa atau Direktorat Jenderal Bea dan Cukai ketika Wajib Pajak mengimpor barang-barang. Dalam hal Ini Wajib Pajak yang dapat insentif dari Pajak Penghasilan Ps. 22 atas impor berdasarkan pasal tersebut yaitu Wajib Pajak yang berklasifikasi memiliki kode KLU sebagaimana tercantum dalam PMK No. 44/2020 atau telah ditetapkan sebagai perusahaan KITE berdasarkan Keputusan Menteri Keuangan ataupun Wajib Pajak yang telah mendapat izin Operator Kawasan Berikat atau izin Pengusaha Kawasan Berikat (izin PDKB). Dalam prosedur yang diperlukan untuk menerapkan insentif ini Wajib Pajak harus mengusulkan permohonan di aplikasi agar Surat keterangan bebas dapat diterbitkan atas pemungutan Pajak Penghasilan Ps. 22 dari Koleksi Impor (SKB Pemungutan) melalui DJP Online. Masa insentif berlaku sejak tanggal dikeluarkannya SKB Pemungutan hingga 30 September 2020. Setiap tiga bulan, Wajib Pajak yang mendapat fasilitas mengenai pembebasan Pajak Penghasilan Pasal 22 atas Impor harus menyerahkan laporan realisasi dengan menggunakan formulir sebagaimana tercantum dalam lampiran M PMK 44/2020 melalui DJP Online selambat-lambatnya pada tanggal $20 \mathrm{Juli}$ 2020, untuk Periode Masa Pajak April 2020 hingga Juni 2020 dan 20 Oktober 2020, untuk Masa Pajak Juli 2020 hingga September 2020. Manfaat bagi Wajib Pajak adalah pembebasan pajak atas pembelian barang dari luar negeri, yang tujuannya sebenarnya adalah memutar roda impor Indonesia agar dapat berjalan sehingga neraca perdagangan dapat terjaga stabil. Wajib Pajak yang memanfaatkan diharap oleh pemerintah dapat menjual barang di Indonesia dengan harga terjangkau oleh masyarakat.

Keempat, Insentif atas Angsuran Pajak Penghasilan (PPh) Ps. 25. Berdasarkan PMK 44/2020, pemerintah memasukkan 846 bidang usaha dalam daftar kode KLU yang berhak mendapatkan potongan 30\% untuk angsuran atas Pajak Penghasilan Ps. 25 Wajib Pajak. Surat Pemberitahuan untuk mendapat pengurangan angsuran Pajak Penghasilan Ps. 25 harus diserahkan oleh Wajib Pajak kepada Kepala Kantor Pelayanan Pajak dimana WP terdaftar melalui DJP Online. Lebih lanjut, Wajib Pajak berkewajiban untuk menyerahkan laporan realisasi pengurangan Pajak Angsuran Pajak Penghasilan Ps. 25 setiap 3 (tiga) bulan melalui DJP Online, di mana laporan tersebut harus menggunakan formulir dari lampiran PMK No. 44/2020 dan selambatnya pada tanggal 20 Juli 2020, untuk Periode Masa Pajak April 2020 hingga Juni 2020 dan tanggal 20 Oktober 2020, untuk Masa Pajak Juli 2020 hingga September 2020. Manfaat bagi Wajib Pajak badan adalah menurunnya setoran yang dibayar atas PPh Ps. 25 setiap bulannya kepada DJP dan dapat menjadi tambahan bantuan dalam arus kas Wajib Pajak badan untuk dapat bertahan dalam masa pandemi, hal ini sesuai dengan tujuan kebijakan untuk membantu para Wajib Pajak badan yang tertekan karena adanya COVID-19. 
Kelima, Insentif atas Pajak Pertambahan Nilai (PPN) yakni dalam bentuk pengembalian permulaan atas pajak sebagai Pengusaha Kena Pajak Berisiko Rendah (PKP Berisiko Rendah) akan diberikan oleh pemerintah untuk mereka yang telah memenuhi kriteria sebagaimana dimaksud dalam bagian peraturan yaitu Pembebasan Pajak Penghasilan Ps. 22 atas Impor dan Wajib Pajak yang telah mengajukan SPT PPN untuk restitusi kelebihan pembayaran dengan jumlah kelebihan pembayaran maksimal Rp 5.000.000.000,00 (lima miliar rupiah). Manfaat bagi Wajib Pajak yang melakukan impor atas barang yakni pengembalian atas kelebih bayar PPN dinyatakan dalam SPT Masa PPN yang dapat menjadi tambahan modal pada arus keuangan perusahaan untuk bertahan menjalankan bisnisnya pada keadaan saat ini.

Kebijakan atas Penurunan Tarif Pajak Pendapatan Wajib Pajak Badan, merupakan pernyataan kebijakan langsung diatur oleh Pemerintah yang sasarannya langsung untuk membantu Wajib Pajak yang terkena dampak pandemi COVID-19. Menurut Peraturan Pemerintah Pengganti Undang (Perppu) No. 1 tahun 2020, tentang Kebijakan Keuangan Negara dan Stabilitas Sistem Keuangan Untuk Penanganan Pandemi COVID-19 Disease 2019 (COVID19) dan/atau Dalam Rangka Menghadapi Ancaman Yang Membahayakan Perekonomian Nasional dan/atau Stabilitas Sistem Keuangan yang diterbitkan dan berlaku per 31 Maret 2020 (Pemerintah Republik Indonesia, 2020). Diperjelas juga dengan Peraturan Direktur Jenderal Pajak Nomor PER 08/PJ/2020 Tentang Penghitungan Angsuran Pajak Penghasilan Untuk Tahun Pajak Berjalan Sehubungan Dengan Penyesuaian Tarif Pajak Penghasilan Wajib Pajak Badan (Direktorat Jenderal Pajak, 2020).

Kebijakan terkait perpajakan sebagaimana dimaksud dalam Ps. 1 ayat (4) Perppu No. 1 tahun 2020 yaitu penyesuaian tarif Pajak Penghasilan Wajib Pajak badan dalam negeri dan bentuk usaha tetap. Merupakan perubahan penurunan tarif Ps. 17 ayat (1) mengenai Pajak Penghasilan yang semula tarif pajak dikenakan 25\% (dua puluh lima persen) akan menjadi sebesar 22\% (dua puluh dua persen) yang berlaku pada Tahun Pajak 2020 dan Tahun Pajak 2021, dan sebesar 20\% (dua puluh persen) yang mulai berlaku pada Tahun Pajak 2022.

Berlaku bagi WP Badan yang telah melantai dibursa saham dengan persyaratan tertentu penyesuaian tarif lebih Pajak Penghasilan rendah 3\% (tiga persen) sebesar 19\% (sembilan belas persen) yang berlaku pada Tahun Pajak 2020 dan Tahun Pajak 2021, dan sebesar 17\% (tujuh belas persen) yang mulai berjalan pada Tahun Pajak 2022. Manfaat bagi Wajib Pajak badan adalah penurunan tarif pajak atas penghasilan usaha mereka dan dapat mempengaruhi arus kas dalam menjalankan usaha.

Dampak pandemi COVID-19 ini sudah banyak yang mengganggu arus kas perusahaan, Pemerintah telah menyusun kebijakan agar dapat merangsang keadaan saat pandemi untuk semua lini yang terdampak mengalami penurunan atau perlambatan agar dapat kembali dan melaju menjadi stabil. Rencana yang telah diumumkan juga terkait meningkatkan batasan restitusi pembayaran kembali pajak yang telah dibayar oleh Wajib Pajak. Saat ini restitusi maksimum untuk Pajak Penghasilan orang pribadi non-karyawan Rp 100.000.000,00 (seratus juta rupiah), untuk Wajib Pajak badan Rp 1.000.000.000,00 (satu miliar rupiah), dan untuk Pengusaha Kena Pajak (PKP) Rp 1.000.000.000,00 (satu miliar rupiah). 
Kenaikannya sampai dengan Rp 5.000.000.000,00 (lima miliar rupiah) untuk meningkatkan arus kas Wajib Pajak, kebijakan ini telah disampaikan dan masih dalam proses finalisasi sampai dengan diumumkan dengan peraturan Menteri keuangan (Kusuma, 2020).

Kebijakan ini diterbitkan oleh pemerintah demi menunjang penanganan pandemi COVID-19 untuk memicu agar dampak dari pandemi COVID-19 dapat berkurang, sehingga terbit Peraturan Menteri Keuangan No. 28/2020 tentang Pemberian Fasilitas Pajak Terhadap Barand dan Jasa yang Diperlukan Dalam Rangka Penanganan Pandemi COVID-19 Disease 2019 (Menteri Keuangan Republik Indonesia, 2020b).

Pertama fasilitas atas pajak pertambahan nilai yaitu diberikan kepada WP atas impor atau perolehan Barang Kena Pajak, perolehan Jasa Kena Pajak, dan/atau pemanfaatan Jasa Kena Pajak dari luar Daerah Pabean di dalam Daerah Pabean yang diperuntukan dalam rangka penanganan dampak pandemi COVID-19 dalam Masa Pajak April 2020 sampai dengan Masa Pajak September 2020.

Kedua adalah fasilitas atas pajak penghasilan yang mana terbagi menjadi 3 (tiga). 1). Pajak Penghasilan Ps. 22 Impor dipungut oleh Bank Devisa atau Direktorat Jenderal Bea dan Cukai dan PPh Ps. 22 dipungut oleh Instansi Pemerintah, badan usaha tertentu dan bergerak dalam bidang usaha industri farmasi berkenaan dengan pembayaran atas pembelian barang, bahan-bahan untuk keperluan kegiatan usahanya atau penjualan hasil produksinya kepada distributor di dalam negeri. 2). penghasilan atas jasa yang dilakukan oleh Wajib Pajak orang pribadi dalam negeri, berupa imbalan dengan nama dan bentuk apapun, dipotong PPh Pasal 21, selain penghasilan atas jasa yang telah dipotong PPh sebagaimana dimaksud dalam Pasal 4 ayat (2) Undang-undang Pajak Penghasilan. 3). Wajib Pajak orang pribadi dalam negeri yang menerima atau memperoleh imbalan dari Pihak Tertentu atas jasa yang diperlukan dalam penanganan pandemi COVID-19, diberikan insentif dari pemotongan Ps. 21 dalam Masa Pajak April 2020 sampai dengan Masa Pajak September 2020.

Ketiga, penghasilan atas jasa teknik, jasa manajemen, jasa konsultan, dan jasa lain selain jasa yang telah dipotong pajak sebagaimana dimaksud dalam Pasal 21 Undang-undang Pajak Penghasilan, yang dilakukan oleh Wajib Pajak badan dalam negeri dan bentuk usaha tetap, berupa imbalan dengan nama dan bentuk apapun, dipotong Pajak Penghasilan Ps. 23. Wajib Pajak badan dalam negeri dan bentuk usaha tetap yang menerima atau memperoleh imbalan dari Pihak Tertentu atas jasa yang diperlukan dalam rangka penanganan pandemi COVID-19, diberikan pembebasan dari pemotongan Pajak Penghasilan Ps. 23 dalam Masa Pajak April 2020 sampai dengan Masa Pajak September 2020.

Manfaat bagi Wajib Pajak adalah menurunnya tarif dan pembebasan atas PPh berkaitan dengan melakukan usaha atas barang atau jasa dalam penanganan COVID-19. Hal ini dapat menjadi tambahan modal dan tambahan penghasilan bagi Wajib Pajak karena pajak atas penghasilan yang selama ini telah dipotongkan ditanggung oleh pemerintah. 


\section{SIMPULAN}

Berdasarkan hasil penelitian dapat diambli kesimpulan jika semua negara anggota ASEAN telah melakukan upaya untuk dapat mengurangi dampak dari pandemi COVID-19. Pemerintah Indonesia dengan peraturan perundangundangan sebagai produk dari kebijakan yang menyangkut kepentingan publik, telah mengerahkan usahanya dalam menyusun kebijakan agar dapat merangsang keadaan saat pandemi untuk semua lini yang terdampak mengalami penurunan atau perlambatan agar dapat naik kembali dan laju pertumbuhannya menjadi stabil kembali.

Manfaat kebijakan bagi Wajib Pajak yaitu penurunan tarif sampai dengan pembebasan atas pajak yang dikenakan sehubungan dengan penghasilan didapat oleh Wajib Pajak. Gunanya untuk menjadi tambahan penghasilan bagi Wajib Pajak Pribadi (WPOP), karena ditanggungnya pajak atas penghasilan mereka. Tambahan modal dalam arus kas bagi Wajib Pajak Badan (WP-Badan) dimanfaatkan seperti menurunnya setoran yang dibayar atas PPh Ps. 25 dan penurunan tarif pajak atas penghasilan usaha kerena telah terjadi pengurangan aktivitas atau bahkan menghentikan usaha karena dampak dari COVID-19. Pemerintah juga memberikan insentif bagi Wajib Pajak UMKM yaitu penurunan tarif pajak agar manfaatnya dapat dijadikan inovasi dalam usaha dan bertahan pada masa pandemi seperti ini. Dalam penanganan dampak dari wabah COVID19, pemerintah juga memberikan insentif kepada Wajib Pajak yang membantu dalam penanganan COVID-19 seperti menurunnya tarif dan pembebasan atas $\mathrm{PPh}$, bertujuan untuk mempercepat penanganan dampak dari COVID-19.

Keterbatasan penelitian ini tidak lepas dari kekurangan dan kelemahan dalam pencarian data sekunder sehingga untuk menindaklanjuti kemanfaatan kebijakan pajak yang telah dikeluarkan oleh pemerintah, terutama terkait dengan manfaat bagi Wajib Pajak secara langsung dirasakan. Analisis lebih lanjut dapat menggunakan pendekatan kuantitatif agar dapat menemukan hasil berbasis data primer yang dapat diuji validitas dan reliabilitasnya secara statistik, sehingga dapat melengkapi penelitian ini sebagai respon manfaat bagi Wajib Pajak berkaitan dengan kebijakan pajak yang dikeluarkan pemerintah dimasa pandemi COVID-19.

\section{REFERENSI}

Antara, Pryanka, A., \& Candra, S. A. (2020, June 11). Empat Sektor Ekonomi yang Paling Tertekan Pandemi Covid-19. Republika.Co.Id, p. https://republika.co.id/berita/q83llp409/empat-sek.

Arvita, R., \& Sawarjuwono, T. (2020). Etika Profesional Konsultan Pajak Dalam Melaksanakan Perannya Sebagai Mitra Wajib Pajak Dan Pemerintah. EJurnal Akuntansi, 30(1), 88-100. https://doi.org/https://doi.org/10.24843/EJA.2020.v30.i01.p07

CNN Indonesia. (2020, February 4). Mengenal 7 Virus Corona yang Jangkiti Manusia. CNN Indonesia. Retrieved from https://www.cnnindonesia.com/teknologi/20200203155532-199-

471187/mengenal-7-virus-corona-yang-jangkiti-manusia

Direktorat Jenderal Pajak. Peraturan Direktur Jenderal Pajak Nomor PER - 08 /PJ /2020, Pub. L. No. PER-08 / PJ / 2020 (2020). Indonesia. 
Economic Organisation for Co-operation and Development. (2020). covid-19 tax policy and other measures. Oecd.Org. Retrieved from https://www.oecd.org/coronavirus/en/

Faisal, M., \& Nirmala, M. P. (2020). COVID-19 and Economic Policy Options: What Should the Government do? Jurnal Inovasi Ekonomi, 5(3), 45-52. https://doi.org/10.22219/jiko.v5i3.11834

Hadiwardoyo, W. (2020). Kerugian Ekonomi Nasional Akibat Pandemi Covid-19. Baskara: Journal of Business and Entrepreneurship, 2(2), 83-92. https:/ / doi.org/10.24853/ baskara.2.2.83-92

Hamzah, A. (2019). Metode Penelitian Kualitatif. Batu: Literasi Nusantara.

Harahap, M., Sinaga, B. M., Manurung, A. H., \& Maulana, T. N. A. (2018). Dampak Kebijakan Dan Makroekonomi Terhadap Efektivitas Penerimaan Pajak Di Bursa Efek Indonesia. Jurnal Ilmiah Manajemen, 8(2). https:/ / doi.org/dx.doi.org/10.22441/mix.2018.v8i2.013

Ihsanuddin. (2020, March 2). Jokowi Umumkan Dua WNI Positif Corona di Indonesia. Kompas.Com. Retrieved from https:/ / nasional.kompas.com/read/2020/03/02/11265921/breaking-newsjokowi-umumkan-dua-orang-di-indonesia-positif-corona?page=all

Kusuma, H. (2020, March 10). Sri Mulyani Naikkan Batasan Restitusi Hingga Rp 5 Miliar. Detik.Com. Retrieved from https://finance.detik.com/beritaekonomi-bisnis/d-4932881/sri-mulyani-naikkan-batasan-restitusi-hinggarp-5-miliar\%0AMau

Menteri Keuangan Republik Indonesia. Peraturan Menteri Keuangan Republik Indonesia Nomor 23/PMK.03/2020, Pub. L. No. PMK 23/PMK.03/2020 (2020). Indonesia.

Menteri Keuangan Republik Indonesia. Peraturan Menteri Keuangan Republik Indonesia Nomor 28/PMK.03/2020, Pub. L. No. PMK 28/PMK.03/2020 (2020). Indonesia.

Menteri Keuangan Republik Indonesia. Peraturan Menteri Keuangan Republik Indonesia Nomor 44/PMK.03/2020, Pub. L. No. PMK 44/PMK.01/2020 (2020). Indonesia.

Moleong, L. J. (1999). Metodologi Penelitian Kualitatif. Bandung: Remaja Rosdakarya.

Muhyiddin, \& Wardhana, D. (2020). Covid-19 Outbreak and Development Planning in Indonesia. The Indonesian Journal of Development Planning, 4(1). https://doi.org/https://doi.org/10.36574/jpp.v4i1.108

Munandar, M. H. (2020). Analysis The Effectiveness Of Tax Relaxation Due To Covid-19 Pandemy On Indonesian Economic Defense. Lex Scientia Law Review, 4(1), 133-142. https://doi.org/10.15294/lesrev.v4i1.38631

Mustajab, D., Bauw, A., Rasyid, A., Irawan, A., Akbar, M. A., \& Hamid, M. A. (2020). Working from Home Phenomenon as an Effort to Prevent COVID-19 Attacks and Its Impacts on Work Productivity. The International Journal of Applied Business Tijab, 4(9), 13-21. https://doi.org/10.1017/CBO9781107415324.004

Pakpahan, A. K. (2020). Covid-19 Dan Implikasi Bagi Usaha Mikro, Kecil, Dan Menengah. JIHI: Jurnal Ilmu Hubungan Internasional, 20(April), 2-6. https://doi.org/https://doi.org/10.26593/jihi.v0i0.3870.59-64 
Pemerintah Republik Indonesia. Peraturan Pemerintah Pengganti UndangUndang Republik Indonesia Nomor 1 Tahun 2020 tentang Kebijakan Keuangan Negara dan Stabilitas Sistem Keuangan Untuk Penanganan Pandemi Covid-19 dan/atau Dalam Rangka Menghadapi Ancaman Yang Membahayakan Perekonomian N, Pub. L. No. Peraturan Pemerintah Nomor 1 Tahun 2020 (2020). Indonesia.

Ramdhani, A., \& Ramdhani, M. A. (2017). Konsep Umum Pelaksanaan Kebijakan Publik. Jurnal Publik, 11(1), 1-12. https:/ / doi.org/10.1109/ICMENS.2005.96

Sampurno, M. B. T., Kusumandyoko, T. C., \& Islam, M. A. (2020). Budaya Media Sosial, Edukasi Masyarakat, dan Pandemi COVID-19. SALAM: Jurnal Sosial Dan Budaya Syar-I, 7(6), 529-542. https:/ / doi.org/10.15408/sjsbs.v7i5.15210

WHO. (2020). Coronavirus disease COVID-2019. who (Vol. 147). https://doi.org/10.30895/2312-7821-2020-8-1-3-8

Widyaningtyas, N. S. (2020). Hubungan Antara Perilaku Wajib Pajak Dan Kebijakan Pajak Berdasarkan Sudut Pandang Behavioral Accounting. EJurnal Akuntansi, 30(1), 14-27.

Yuliana. (2020). Corona virus diseases (Covid -19): Sebuah tinjauan literatur. Wellness and Healthy Magazine, 2(1), 187-192. Retrieved from https://wellness.journalpress.id/wellness/article/view/21026 


\section{Lampiran 1 : Kebijakan Pajak Indonesia Dari OECD}

\begin{tabular}{|c|c|c|c|}
\hline Jenis Pajak & $\begin{array}{c}\text { Jenis } \\
\text { Pengukuran } \\
\end{array}$ & Diskripsi & $\begin{array}{l}\text { Landasan } \\
\text { Kebijakan }\end{array}$ \\
\hline $\begin{array}{l}\text { Pajak } \\
\text { pendapatan } \\
\text { perusahaan }\end{array}$ & $\begin{array}{l}\text { Mengukur } \\
\text { untuk } \\
\text { meningkatkan } \\
\text { arus kas bisnis }\end{array}$ & $\begin{array}{l}\text { Pajak penghasilan badan akan } \\
\text { berkurang dari } 25 \% \text { menjadi } 22 \% \text { untuk } \\
\text { tahun finansial } 2020 \text { dan } 2021 \text {, dan } 20 \% \\
\text { untuk tahun keuangan } 2022 \text { dan } \\
\text { seterusnya untuk melindungi bisnis } \\
\text { dari masalah likuiditas. }\end{array}$ & $\begin{array}{l}\text { (Perppu) } \\
\text { Nomor } 1 \\
\text { tahun } \\
2020 \\
\text { PER 08 }\end{array}$ \\
\hline $\begin{array}{l}\text { Pajak } \\
\text { Pertambahan } \\
\text { Nilai }\end{array}$ & $\begin{array}{l}\text { Mengukur } \\
\text { untuk } \\
\text { meningkatkan } \\
\text { arus kas bisnis }\end{array}$ & $\begin{array}{l}\text { Pengembalian Pajak Pertambahan Nilai } \\
\text { Pendahuluan hingga Rp } 5 \text { miliar akan } \\
\text { secara otomatis dipertimbangkan oleh } \\
\text { pemerintah. }\end{array}$ & PMK 44 \\
\hline $\begin{array}{l}\text { Pajak } \\
\text { Pertambahan } \\
\text { Nilai }\end{array}$ & $\begin{array}{l}\text { Mengukur } \\
\text { untuk } \\
\text { meningkatkan } \\
\text { arus kas bisnis }\end{array}$ & 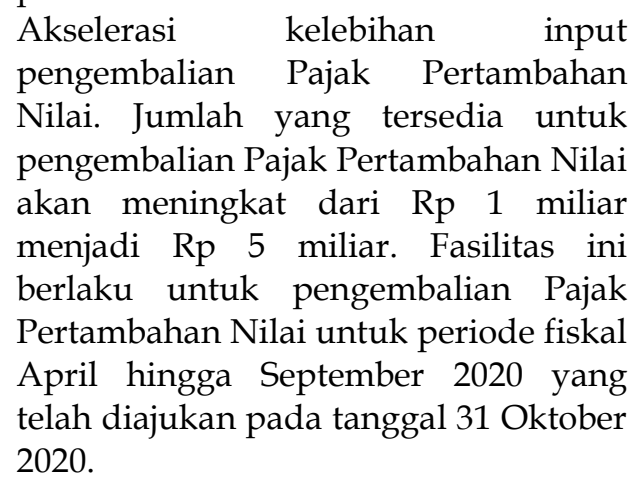 & $\begin{array}{l}\text { Masih } \\
\text { dalam } \\
\text { Proses } \\
\text { Finalisasi }\end{array}$ \\
\hline $\begin{array}{l}\text { Pajak } \\
\text { pendapatan } \\
\text { perusahaan }\end{array}$ & $\begin{array}{l}\text { Mengukur } \\
\text { untuk } \\
\text { meningkatkan } \\
\text { arus kas bisnis }\end{array}$ & $\begin{array}{l}\text { Pengurangan } 30 \% \text { pembayaran cicilan } \\
\text { pajak bulanan untuk perusahaan yang } \\
\text { bergerak di salah satu dari } 102 \text { bidang } \\
\text { usaha dan / atau ditetapkan sebagai } \\
\text { perusahaan KITE (Fasilitas Impor } \\
\text { untuk Tujuan Ekspor) hingga } 30 \\
\text { September 2020. }\end{array}$ & PMK 44 \\
\hline $\begin{array}{l}\text { Pajak } \\
\text { pendapatan } \\
\text { perusahaan }\end{array}$ & $\begin{array}{l}\text { Mengukur } \\
\text { untuk } \\
\text { meningkatkan } \\
\text { arus kas bisnis }\end{array}$ & $\begin{array}{l}\text { Atas permintaan wajib pajak, } \\
\text { pengurangan } 30 \% \text { dalam angsuran } \\
\text { pajak pendapatan perusahaan bulanan } \\
\text { (yaitu pembayaran di muka) akan } \\
\text { diberikan. Langkah ini akan berlaku } \\
\text { untuk periode fiskal yang berakhir } \\
\text { pada September 2020. }\end{array}$ & PMK 44 \\
\hline Lain-lain & $\begin{array}{l}\text { Mengukur } \\
\text { untuk } \\
\text { mendukung } \\
\text { sistem } \\
\text { kesehatan }\end{array}$ & $\begin{array}{l}\text { Insentif pajak untuk barang dan jasa } \\
\text { yang diperlukan dalam menanggulangi } \\
\text { penyakit virus korona } 2019 \text { untuk } \\
\text { periode April-September } 2020 \\
\text { (pembebasan beberapa pajak yang } \\
\text { dipotong) }\end{array}$ & PMK 28 \\
\hline Lain-lain & $\begin{array}{l}\text { Mengukur } \\
\text { untuk } \\
\text { mendukung } \\
\text { sistem } \\
\text { kesehatan }\end{array}$ & $\begin{array}{l}\text { Instansi pemerintah, swasta, dan sektor } \\
\text { lain tertentu yang menjual atau } \\
\text { membeli barang untuk melawan } \\
\text { COVID-19 (orang yang memenuhi } \\
\text { syarat) akan diberikan Pajak } \\
\text { Pertambahan Nilai, pajak penghasilan } \\
\text { dan insentif pajak impor. Langkah ini }\end{array}$ & PMK 28 \\
\hline
\end{tabular}




\begin{tabular}{|c|c|c|c|}
\hline Jenis Pajak & $\begin{array}{c}\text { Jenis } \\
\text { Pengukuran }\end{array}$ & Diskripsi & $\begin{array}{l}\text { Landasan } \\
\text { Kebijakan }\end{array}$ \\
\hline & & $\begin{array}{l}\text { akan berlaku dari Periode Pajak April } \\
2020 \text { hingga Periode Pajak September } \\
2020 \text {. }\end{array}$ & \\
\hline $\begin{array}{l}\text { Pajak } \\
\text { pendapatan } \\
\text { perusahaan }\end{array}$ & $\begin{array}{l}\text { Mengukur } \\
\text { untuk } \\
\text { meningkatkan } \\
\text { arus kas bisnis }\end{array}$ & $\begin{array}{l}\text { Pemerintah akan menanggung } 0,5 \% \\
\text { dari pajak penghasilan final atas pajak } \\
\text { UKM yang omset tahunannya } \\
\text { mencapai Rp } 4,8 \text { miliar. }\end{array}$ & PMK 44 \\
\hline $\begin{array}{l}\text { Pajak } \\
\text { pendapatan } \\
\text { pribadi }\end{array}$ & $\begin{array}{l}\text { Langkah untuk } \\
\text { meningkatkan } \\
\text { arus kas rumah } \\
\text { tangga }\end{array}$ & $\begin{array}{l}\text { Pemerintah akan menanggung biaya } \\
\text { Pajak Penghasilan untuk bulan April } \\
\text { hingga September } 2020 \text { untuk } \\
\text { karyawan tertentu seperti penghasilan } \\
\text { tahunan tidak melebihi Rp } 200 \text { juta }\end{array}$ & PMK 44 \\
\hline $\begin{array}{l}\text { Pajak } \\
\text { konsumsi } \\
\text { lainnya }\end{array}$ & $\begin{array}{l}\text { Mengukur } \\
\text { untuk } \\
\text { meningkatkan } \\
\text { arus kas bisnis }\end{array}$ & $\begin{array}{l}\text { Bea masuk dapat dikecualikan untuk } \\
\text { perusahaan yang bergerak di salah satu } \\
\text { dari } 102 \text { bidang usaha dan/atau } \\
\text { ditunjuk sebagai perusahaan KITE } \\
\text { (Fasilitas Impor untuk Tujuan Ekspor) } \\
\text { hingga } 30 \text { September } 2020 \text {. }\end{array}$ & PMK 44 \\
\hline $\begin{array}{l}\text { Pajak } \\
\text { konsumsi } \\
\text { lainnya }\end{array}$ & $\begin{array}{l}\text { Mengukur } \\
\text { untuk } \\
\text { meningkatkan } \\
\text { arus kas bisnis }\end{array}$ & $\begin{array}{l}\text { Pemerintah membebaskan atau } \\
\text { membebaskan pajak impor untuk } \\
\text { perusahaan manufaktur di } 19 \text { sektor } \\
\text { selama periode enam bulan. }\end{array}$ & PMK 44 \\
\hline $\begin{array}{l}\text { Pajak } \\
\text { pendapatan } \\
\text { perusahaan }\end{array}$ & $\begin{array}{l}\text { Langkah untuk } \\
\text { meningkatkan } \\
\text { arus kas rumah } \\
\text { tangga }\end{array}$ & $\begin{array}{l}\text { Pembebasan Pajak Penghasilan atas } \\
\text { impor yang dilakukan oleh Wajib Pajak } \\
\text { Badan tertentu selama } 6 \text { bulan (April } \\
\text { hingga September 2020). }\end{array}$ & PMK 44 \\
\hline $\begin{array}{l}\text { Peringanan } \\
\text { pajak }\end{array}$ & $\begin{array}{l}\text { Kebijakan } \\
\text { pajak } \\
\text { mendukung } \\
\text { pekerjaan }\end{array}$ & $\begin{array}{l}\text { Pemotongan Uang Muka uang muka } \\
\text { dihapuskan untuk bisnis untuk periode } \\
\text { April hingga September } 2020 \text { dalam } \\
\text { kondisi tertentu, seperti pengusaha } \\
\text { yang terlibat dalam bisnis dan } \\
\text { pendapatan karyawan tertentu yang } \\
\text { tidak melebihi Rp } 200 \text { juta. }\end{array}$ & PMK 44 \\
\hline $\begin{array}{l}\text { Pajak } \\
\text { pendapatan } \\
\text { pribadi }\end{array}$ & $\begin{array}{l}\text { Langkah untuk } \\
\text { meningkatkan } \\
\text { arus kas rumah } \\
\text { tangga }\end{array}$ & $\begin{array}{l}\text { Pengecualian untuk pekerja } \\
\text { manufaktur dari pajak penghasilan. } \\
\text { Pekerja dalam ruang lingkup adalah } \\
\text { mereka yang menghasilkan Rp } 200 \text { juta } \\
\text { rupiah atau kurang setahun. }\end{array}$ & $\begin{array}{l}\text { PMK } \\
23 / \text { PMK } \\
44\end{array}$ \\
\hline
\end{tabular}

Sumber: Data Penelitian, 2020 